\title{
Pleural Mesothelioma TNM Finding v7
}

National Cancer Institute

\section{Source}

National Cancer Institute. Pleural Mesothelioma TNM Finding v7. NCI Thesaurus. Code C88895.

A finding about one or more characteristics of pleural mesothelioma, following the rules of the TNM AJCC V7 classification system. The staging system used in the AJCC 7th edition represents an adoption of the system proposed in 1995 by the International Mesothelioma Interest Group (IMIG), which was based on updated information about the relationship between tumor T and N status and overall survival. (from AJCC 7th Ed.) 